\title{
Strategi Menjadi Kepala Sekolah Profesional
}

\author{
Mohamad Muspawi \\ Universitas Jambi \\ Corresponding email: muspawi01@gmail.com
}

\begin{abstract}
Abstrak. Kepala sekolah adalah seorang tenaga pengajar yang diberikan amanah atau diangkat menjadi seorang pemimpin di sekolah dengan cara yang formal, dan memiliki tugas memberdayakan dan memberikan contoh dalam konteks memimpin semua warga yang ada di sekolah, agar dapat meningkatkan mutu sekolah yang dipimpinnya. Kepala sekolah dituntut agar selalu menjadi seorang figur yang dapat menjadi penengah, pengambilan keputusan dan pemecahan masalah serta dapat menjadikan dirinya sebagai sumber informasi bagi warga sekolah yang dipimpinnya. Serangkaian strategi yang dapat dilakukan untuk menjadi kepala sekolah profesional adalah: 1). Taat aturan. 2). Meluangkan waktu. 3). Peduli dan cepat tanggap. 4). Pemanfaatan IT. 5). Pendampingan Akademik. 6). Inovatif.
\end{abstract}

Kata kunci: Strategi; Kepala Sekolah; Profesional

Abstract. The school principal is a teacher who is given the mandate or appointed as a leader in the school in a formal way, and has the task of empowering and giving examples in relationships that connect all citizens in the school, in order to improve the school they lead. The principal is demanded to always be a figure who can mediate, make decisions and solve problems can also make it as a source of information for the residents of the school they lead. A series of strategies that can be done to become a professional school principal are: 1). Obey the rules. 2). Taking the time. 3). Caring and responsive. 4). IT Utilization. 5). Academic Assistance. 6). Innovative.

Keywords: Strategy; School Principal; Professional

\section{PENDAHULUAN}

Keberadaan kepala sekolah di sebuah sekolah laksana seorang nahkoda di sebuah kapal, ia menjadi pengendali dan penentu kemana arah kapal tersebut melaju dan berlabuh. Begitu juga kepala sekolah, ia merupakan pengendali dan penentu kemana arah sekolah yang dipimpinnya bergerak dan apa target yang dituju.

Peran kepala sekolah memang begitu sentral sehingga Mahardhani (2015) mengatakan bahwa kepala sekolah menjadi kunci utama dan merupakan salah satu faktor strategi yang paling penting dalam mengembangkan sekolah yang bermutu. Muspawi, et.all (2020) mengatakan keberhasilan mencapai tujuan pendidikan di sebuah sekolah banyak disandarkan pada kepiawaian seorang kepala sekolah dalam memimpin, dengan kepemimpinan yang baik segala potensi yang dimiliki oleh sekolah akan bergerak dan berkembang sesuai dengan kebutuhan dan perkembangan zaman.

Kepala sekolah adalah seorang guru yang diangkat untuk menduduki jabatan struktur tertinggi atau kepala sekolah di sekolah Yahya (2013). Kepala sekolah dalam menjalankan tugasnya harus bertindak secara profesional, yakni bertugas sesuai dengan tugas pokok dan fungsi sebagaimana yang telah diamanahkan oleh peraturan yang berlaku. Kepala profesional berupaya menjalankan perannya sebagai pemimpin dengan baik. Yuliani \& Kristiawan (2016) mengatakan bahwa kepemimpinan menyangkut sebuah proses pengaruh sosial yang dalam hal ini pengaruh yang disengaja dijalankan oleh seseorang terhadap orang lain untuk menstruktur aktivitas serta hubungan di dalam sebuah kelompok atau organisasi.

Menjadi kepala sekolah profesional merupakan pencapaian ideal dari perjalanan seorang kepala sekolah. Menjadi kepala sekolah profesional juga merupakan sebuah keniscayaan, sebab begitu banyak penelitian membuktikan bahwa kepemimpinan kepala sekolah mempengaruhi berbagai aspek dalam dunia pendidikan, seperti Harso (2012) yang membuktikan pengaruh kepemimpinan kepala sekolah dan kinerja guru terhadap keefektifan sekolah di SMK kabupaten Pemalang, Septiana, et.all (2013) yang membuktikan pengaruh kepemimpinan kepala sekolah dan motivasi kerja terhadap kinerja guru SMP Negeri Wonosari, Syakir \& Pardjono (2015) yang membuktikan pengaruh kepemimpinan kepala sekolah, motivasi kerja, dan budaya organisasi terhadap kompetensi guru SMA.

Harapan besar digantungkan di pundak seorang kepala sekolah, dengan harapan melalui kerja profesional ia dapat membawa sekolah yang dipimpinnya ke arah yang lebih baik dari sebelumnya, dan menghadirkan kemaslahatan serta kesejahteraan bagi semua warga sekolah.

\section{METODE}

Metode yang penulis gunakan dalam penelitian ini adalah metode Library Research yakni penelitian kepustakaan, sebagaimana pendapat Nazir (2003:111) bahwa Studi kepustakaan adalah teknik pengumpulan data dengan mengadakan studi penelaahan terhadap buku-buku, literatur-literatur, catatan-catatan, dan 
laporan-laporan yang ada hubungannya dengan masalah yang dipecahkan. Dalam hal ini penulis memperdalam, mengkaji, dan menelaah literatur-literatur yang berkaitan dengan kepala sekolah, kemudian penulis melakukan analisis yang mendalam, dan selanjutnya penulis susun dalam bentuk artikel ilmiah.

\section{HASI DAN PEMBAHASAN Pengertian Kepala Sekolah}

Kepala sekolah menurut Kamus Besar Bahasa Indonesia (Depdiknas, 2005: 549) ialah orang (guru) yang memimpin suatu sekolah, atau disebut juga sebagai guru kepala. Wahjosumidjo (2005: 83) mengatakan bahwa kepala sekolah adalah tenaga fungsional guru yang diberi tugas untuk memimpin suatu sekolah dimana diselenggarakan proses belajar mengajar atau tempat dimana terjadi interaksi antara guru yang memberi pelajaran dan murid yang menerima pelajaran.

Asmani (2012) mengatakan bahwa kepala sekolah dapat didefinisikan sebagai pemimpin sekolah atau suatu lembaga tempat menerima dan member pelajaran. Yahya (2013) mengatakan kepala sekolah adalah seorang guru yang diangkat untuk menduduki jabatan struktur tertinggi atau kepala sekolah di sekolah.

Sedangkan pengertian kepala sekolah menurut Peraturan Menteri Pendidikan Nasional No.28 Tahun 2010 ialah guru yang diberi tugas tambahan untuk memimpin Taman Kanak-Kanak/ Raudhotul Athfal (TK/RA), Taman Kanak-Kanak Luar Biasa (TKLB), Sekolah/Madrasah Ibtidaiyah (SD/MI), Sekolah Dasar Luar Biasa (SDLB), Sekolah Menengah Pertama/ Madrasah Tsanawiyah (SMP/MTs), Sekolah Menengah Pertama Luar Biasa (SMPLB), Sekolah Menengah Atas/ Madrasah Aliyah (SMA/MA), Sekolah Menengah Kejuruan/ Madrasah Aliyah Kejuruan (SMK/MAK), Sekolah Menengah Atas Luar Biasa (SMALB) yang bukan Sekolah Bertaraf Internasioanal (SBI) atau yang tidak dikembangkan menjadi Sekolah Bertaraf Internasional (SBI).

Berdasarkan beberapa penjelasan tersebut, dapat penulis simpulkan bahwa pengertian kepala sekolah adalah seorang guru yang diangkat dan ditugaskan secara formal menjadi pemimpin bagi sebuah sekolah untuk memberdayakan dan memimpin sumber daya sekolah dalam rangka meningkatkan mutu sekolah.

\section{Kualifikasi Kepala Sekolah}

Kualifikasi seorang kepala sekolah menurut Peraturan Menteri Pendidikan Nasional RI No 13 Tahun 2007 Tentang Standar Kepala Sekolah, diantaranya :

1. Beberapa kualifikasi Umum Kepala Sekolah/Madrasah adalah sebagai berikut: a. Memiliki kualifikasi akademik diploma empat (DIV) atau sarjana (S1) non kependidikan atau kependidikan pada perguruan tinggi yang terakreditasi. b. Batas usia saat diangkat menjadi pemimpin sekolah setinggi-tingginya berusia 56 tahun. c. Menurut jenjang sekolah masing-masing, sekurang-kurangnya memiliki pengalaman mengajar selama 5 (lima) tahun kecuali di Taman Kanakkanak/ Raudhatul Athfal (TK/RA), sekurang-kurangnya memiliki pengalaman mengajar selama 3 (tiga) tahun di TK/RA, dan d. Bagi yang non-PNS harus disetarakan dengan kepangkatan dan serendahrendahnya memiliki pangkat $\mathrm{III} / \mathrm{c}$ bagi pegawai negeri sipil (PNS) yang dikeluarkan oleh yayasan atau lembaga yang berwenang.

2. Beberapa kualifikasi Khusus Kepala Sekolah Dasar/ MI meliputi: a. Berstatus sebagai guru Sekolah Dasar/ MI. b. Memiliki piagam pendidik sebagai guru Sekolah Dasar/ MI, dan c. Memiliki piagam pemimpin Sekolah Dasar /MI yang ditetapkan dan diterbitkan oleh lembaga pemerintahan. Sedangkan kompetensi yang harus dimiliki oleh pemimpin sekolah diantaranya kompetensi sosial, manajerial, kepribadian, supervisi, dan kewirausahaan.

\section{Tugas Pokok dan Fungsi Kepala Sekolah}

Tugas pokok kepala sekolah dijelaskan di dalam Permendikbud RI Nomor 6 Tahun 2018 bab 6 pasal 15 sebagai berikut: (1) Beban kerja kepala sekolah sepenuhnya untuk melaksanakan tugas pokok manajerial, pengembangan kewirausahaan, dan supervisi kepada Guru dan tenaga kependidikan. (2) Beban kerja kepala sekolah sebagaimana dimaksud pada ayat (1) bertujuan untuk mengembangkan sekolah dan meningkatkan mutu sekolah berdasarkan 8 (delapan) standar nasional pendidikan. (3) Dalam hal terjadi kekurangan guru pada satuan pendidikan, Kepala Sekolah dapat melaksanakan tugas pembelajaran atau pembimbingan agar proses pembelajaran atau pembimbingan tetap berlangsung pada satuan pendidikan yang bersangkutan. (4) Kepala Sekolah yang melaksanakan tugas pembelajaran atau pembimbingan sebagaimana dimaksud pada ayat (3), tugas pembelajaran atau pembimbingan tersebut merupakan tugas tambahan di luar tugas pokoknya. (5) Beban kerja bagi kepala sekolah yang ditempatkan di Sekolah Indonesia Luar Negeri (SILN) selain melaksanakan beban kerja sebagaimana dimaksud pada ayat (1) dan ayat (3) juga melaksanakan promosi kebudayaan Indonesia.

Adanya beragam tugas dan tanggung jawab kepala sekolah dalam mengelola sekolah. Menurut Lazaruth Soewadji (1992: 68), kepala sekolah memiliki bertugas dan bertanggung jawab dalam mengembangkan setiap mutu sekolah, melalui pembinaan siswa, guru, dan anggota staf yang lain. Dapat kita lihat lebih lanjut lagi yang dijelaskan, bahwa pemimpin kependidikan sebagai kepala sekolah harus mampu mengartikan aspirasiaspirasi dan keinginan-keinginan bawahannya, sehingga apa yang diharapkan bersama-sama dapat dicapai. Pemimpin kependidikan juga berkewajiban untuk selalu mengadakan bimbingan yang berarti berusaha agar 
pengelolaan, penilaian, bimbingan, pengawasan, dan pengembangan pendidikan dapat dilaksanakan dengan lebih baik (Wahjosumidjo, 2005: 203).

Lengkap dan berbeda yang dimiliki dari pendidikan membuat terciptanya peran kepala sekolah untuk mewujudkan tercapainya tujuan pendidikan yang sangat fundamental. Sehingga dapat disimpulkan keberhasilan kepala sekolah identik dengan keberhasilan pendidikan. Kepala sekolah dapat dikatakan berhasil juga dapat dilihat dari sekolah yang dipimpinnya maju dan terus berkembang.

Fungsi kepala sekolah dapat dilihat dari beberapa sudut pandang. Bersama dengan dan uniknya institusi pendidikan fungsi kepala sekolah sebagai berikut: sebagai manajer, sebagai pemimpin, dan sebagai pendidik (Wahjosumidjo, 2002:82)

Selain itu, kepala sekolah memiliki atau mencakup tugas pokok dalam 3 bidang yaitu kewirausahaan, supervisi dan manajerial (Darmadi, 2018). Kepala sekolah sebagai edukator mencakup tujuh fungsi aspek yaitu : 1). Prestasi guru, 2). Kemampuan membibimbing guru, 3). Kemampuan membimbing karyawan, 4). Membimbing siswa, 5). Mengembangkan staf, kemampuan belajar dan mengikuti perkembangan iptek dan kemampuan memberi contoh mengajar.tugas kemampuan pemimpin pendidikan sebagai manajer merangkum bdiang kemampuan menyusun progam, menyusun organisasi kepegawaian, menggerakkan staf dan aspek kemampuan mengoptimalkan daya pendidikan.

Wahjosumidjo (2005) menjelaskan paling tidak ada empat hal yang perlu ditanamkan seorang kepala sekolah dalam fungsinya sebagai pendidik, yakni: 1 . Mental, yaitu hal-hal yang berkaitan dengan sikap batin dan watak manusia. 2. Moral, yaitu hal-hal yang berkaitan dengan ajaran baik dan buruk, mengenai perbuatan, sikap dan kewajiban juga moral yang diartikan sebagai akhlak, budi pekerti dan kesusilaan. 3 . Fisik, yakni hal-hal yang berkaitan dengan kondisi jasmani atau badan, kesehatan dan penampilan manusia secara lahiriah. 4) Artistik, yakni hal-hal yang berkaitan dengan kepekaan manusia terhadap seni dan keindahan.

Tugas kepemimpinan pendidikan sebagai administrator merangkum kemampuan mengatur administrasi kegiatan belajar mengajar serta bimbingan dan konseling, kesiswaan,ketenagaan,kedanaan, sarana dan prasarana maupun bidang kemampuan mengatur administrasi persuratan.

Maghfiroh (2010) mengemukakan tugas kepala sekolah sebagai edukator (pendidik), manajer, administrator, supervisor (penyelia), leader (pemimpin), inovator dan motivator (EMASLIM) dapat disingkat menjadi pokok 3 unsur yaitu : 1). Kepala sekolah sebagai manajer didalamnya mencakup fungsi sebagai administrator, dan supervisor. 2). Kepala sekolah sebagai leader didalamnya mencakup fungsi inovator dan educator. 3). Kepala sekolah sebagai educator.

\section{Wewenang dan Tanggung Jawab Kepala Sekolah}

Maghfiroh (2010) menjelaskan wewenang kepala sekolah meliputi 7 bidang yaitu: 1). Bidang akademik yang memiliki hubungan dalam proses belajar mengajar baik itu di luar ruangan maupun di dalam ruangan sekolah atau madrasah. 2). Bidang keuangan dan ketatausahaan sekolah. 3). Bidang kesiswaan. 4). Bidang perlengkapan sekolah dan gedung sekolah. 5). Bidang personalia. 6). Bidang peralatan pelajaran. 7). Bidang masyarakat dan sekolah.

Di dalam Peraturan Pemerintah Republik Indonesia Nomor 28 Tahun 1990 bab VI pasal 12 ayat 1 dijelaskan bahwa Kepala Sekolah bertanggung jawab atas penyelenggaraan kegiatan pendidikan, administrasi sekolah, pembinaan tenaga kependidikan lainnya dan pendayagunaan serta pemeliharaan sarana dan prasarana.

\section{Payung Hukum Kepala Sekolah}

Payung hukum keberadaan kepala sekolah di Indonesia antara lain sebagai berikut: 1) UndangUndang Republik Indonesia Nomor 20 Tahun 2003 tentang Sistem Pendidikan Nasional (SISDIKNAS). 2) Undang-Undang Republik Indonesia Nomor 14 Tahun 2005 Tentang Guru dan Dosen. 3) Peraturan Menteri Pendidikan Nasional Nomor 13 Tahun 2007 tentang Standar Kepala Sekolah/ Madrasah. 4. Peraturan Menteri Pendidikan Nasional Nomor 28 tahun 2010 Tentang Penugasan Guru Sebagai Kepala Sekolah/ Madrasah. 5) Peraturan Menteri Pendidikan dan Kebudayaan Nomor 6 tahun 2018 Tentang Penugasan Guru Sebagai Kepala Sekolah. 6) Peraturan Menteri Pendidikan dan Kebudayaan Republik Indonesia Nomor 39 Tahun 2012 tentang Organisasi Dan Tata Kerja Lembaga Pengembangan Dan Pemberdayaan Kepala Sekolah. 7) Peraturan Menteri Pendidikan Dan Kebudayaan Republik Indonesia Nomor 45 Tahun 2013 tentang Rincian Tugas Lembaga Pengembangan Dan Pemberdayaan Kepala Sekolah. 8) Peraturan Menteri Pendidikan Dan Kebudayaan Republik Indonesia Nomor 15 Tahun 2018 tentang Pemenuhan Beban Kerja Guru, Kepala Sekolah, Dan Pengawas Sekolah.

\section{Kewajiban Kepala Sekolah}

Dedy Mulyasana dalam Nurmadiah (2017) merangkum kewajiban kepala sekolah di antaranya sebagai berikut: 1) Menguraikan visi kedalam misi sasaran mutu (kualitas). 2) Menyusun target dan tujuan yang ingin dicapai. 3) Mengkaji terkait peluang, tantangan, kelemahan serta kekuatan yang dimiliki sekolah. 4) Membentuk rencana kerja tahunan dan rencana kerja strategis guna melaksanakan pengembangan mutu. 5) Bertanggung jawab ketika membuat keputusan dana sekolah. 6) Mengikutsertakan komite dan guru sekolah ketika mengambil sebuah keputusan yang penting. 7) Menciptakan hubungan yang intens dari orang tua dan masyarakat. 8) Meningkatkan dan mempertahankan motivasi kerja pendidik dan tenaga 
kependidikan dengan memanfaatkan cara dengan memberikan apresiasi terhadap suatu pencapaian serta memberikan sanksi mengenai pelanggaran terhadap kode etik dan peraturan. 9) Mewujudkan lingkungan belajar yang efektif. 10) Bertanggung jawab dalam merencanakan pelaksanaan kurikulum disekolah. 11) Menyelenggarakan serta menyusun program supervisi. 12) Meningkatkan kualitas pendidikan. 13) Menjaga nama baik profesi, kedudukan dan lembaga sesuai amanah yang telah diemban dan dapat memberikan teladan. 14) Memberikan fasilitas untuk penyebarluasan dan pengembangan serta melaksanakan tujuan pembelajaran mendukung dan mengkomunikasikan dengan baik kepada seluruh warga sekolah. 15) Membina, mempertahankan serta membantu lingkungan sekolah dan mendukung kegiatan belajar mengajar yang kondusif dan menumbuhkan profesionalisme tenaga pendidik 16) Pengelolaan sekolah serta pendayagunaan sumber daya yang sering digunakan untuk mewujudkan lingkungan yang sehat, efektif efisien dan aman harus dipertanggung-jawabkan. 17) Membentuk kerjasama antara orang tua siswa, masyarakat dan komite dalam melayani kepentingan serta kebutuhan seluruh elemen yang terkait dan menggerakkan masyarakat. 18) Kepala sekolah dapat melimpahkan sebagian wewenang dan tugas sesuai dengan bidang nya kepada wakil kepala sekolah.

Menurut Jelantik (2015) Sebagai pemimpin yang menentukan dinamika sekolah menuju kemajuan di segala bidang dan gerbang kesuksesan kehidupan. Di satu sisi keterampilan, emosional, intelektual, sosial, spiritual dan kecakapan memiliki pengaruh yang cukup besar terhadap cara kepemimpinan. Begitu juga kewibawaan dan relevansi komunikasi serta kedalaman ilmu, keluasan pikiran membawa perubahan dalam mengelola sekolah. Maka dari itu, kepala sekolah dituntut selalu dapat mematangkan keterampilan, emosional, sosial, intelektual, spiritual dan kecakapan. Dapat melanjutkan pendidikan sampai dengan ke jenjang pendidikan yang tinggi, organisasi sosial serta rajin ibadah merupakan kunci kesuksesan bagi seorang pemimpin sehingga kepemimpinannya dapat memiliki arti dan kepemimpinannya tidak akan membawa perubahan formal saja tetapi ada kultur yang dapat tertanam dalam perilaku. Berbagai kegiatan manajerial yang perlu dilaksanakan pemimpin juga menjadi tanggung jawabnya misalnya dalam hal proses belajar mengajar, administrasi siswa, administrasi pegawai, administrasi perlengkapan, administrasi kantor, administrasi perpustakaan, administrasi hubungan masyarakat dan administrasi keuangan. Pemimpin juga bertanggung jawab dalam melakukan penyediakan dukungan seperti halnya dana, sarana, maupun iklim akademik yang bagus bagi pengembangan kompetensi guru, siswa, maupun tenaga kependidikan.

Kepala sekolah dalam melaksanakan kepemimpinannya wajib: Beriman Kepada Tuhan Yang
Maha Esa, bersikap demokratis, jujur, adil, bijaksana dan sopan dengan demikian dapat dijadikan sebagai teladan untuk masyarakat sekolah, dapat memberikan suasana yang kondusif, mewujudkan suatu kerjasama dengan guru, upaya agar dapat meningkatkan pengetahuan dan keterampilan, kemampuan dan kenyamanan warga sekolah, memiliki sifat terbuka dalam melaksanakan kewajiban serta tanggung jawab, perasa terhadap setiap perkembangan, melakukan pembaharuan demi kemajuan ilmu pengetahuan serta teknologi. Dalam memelihara disiplin, 30 menit sebelum dimulai kegiatan belajar mengajar sudah hadir terlebih dahulu dan pulang sekolah setelah pembelajaran usai, berdomisili di lingkungan sekitar sekolah, melakukan absensi, memiliki dan mempunyai absen guru, memberikan reward tentang prestasi kerja, mengeluarkan peringatan dan teguran serta hukuman terhadap guru jika melakukan kesalahan cara bertahap, harus berpenampilan rapi, sopan dan bersih.

\section{Prinsip kepala sekolah}

Fullan (2001) mengatakan terdapat lima prinsip yang harus ditegakkan kepala sekolah yaitu: 1) Orientasi pada tercapainya tujuan. 2) Melaksanakan kepemimpinan partisipatif dengan cara mengembangkan peran pendidik dalam mengambil kepeutusan. 3) Harus menjadi pemimpin yang dapat mengeluarkan ide baru melalui peningkatan keyakinan dalam dirinya kepada dengan memperluas tindakan yang dapat mendorong terjadinya perubahan. 4) Dapat memberikan keyakinan sehingga timbul persepsi dari pendidik bahwa kepala sekolah menunjang kegiatan bekerja. 5) Memperluas kerjasama antar pendidik baik melalui interaksi formal atau informal.

Mada Sutapa (2016 :75) menjelaskan kepala sekolah menciptakan komunikasi yang efektif menerapkan prinsip berikut: 1) Prinsip human relations. Kepala sekolah sebagai pemimpin sering kali berhubungan atau berinteraksi dengan orang lain dan upaya membangun komunikasi yang efektif baik kepada guru, staf, siswa serta stakeholder terkait. 2) Prinsip membina hubungan. Kepala sekolah sebagai pemimpin harus kreatif serta inovatif (dapat menemukan ide-ide baru) dalam mengatur hubungan dengan staff, guru, siswa, terutama dalam hal pemberian motivasi. Sedangkan dengan stakeholder dan orang tua siswa harus menjalin kerjasama yang saling menguntungkan seperti bantuan sarana dan prasarana, kelancaran kegiatan belajar mengajar dan beasiswa. 3) Prinsip informativ. Pemimpin yaitu seorang kepala yang harus menyampaikan informasi yang strategis terhadap warga sekolah internal maupun eksternal dan kepala sekolah juga harus mampu mengelola informasi sebelum disampaikan. 4) Prinsip partisipatif. Kepala sekolah sebagai pemimpin harus mampu menggali saran dan aspirasi baik dari orang tua, masyarakat, staff dan guru dalam mengambil sebuah keputusan. 5) Prinsip 
persuasif. Kepala sekolah sebagai pemimpin harus mampu mempengaruhi orang lain bersikap jujur, dapat dipercaya, objektif dan memperhatikan dalam hal pelayanan serta harus bersikap professional. 6) Prinsip komunikasi interpersonal. Pemimpin sebagai seseorang yang dianut terus menjalin dan membangun komunikasi dengan baik terhadap warga sekolah secara dialogis

\section{Kode etik kepala sekolah}

Menurut Zacky (2016) NEA pertama kali merumuskan kode etik tenaga kependidikan tahun 1929 yang berjudul "A Code Ethics for The Teaching Profession". Setelah itu kode etik tersebut direvisi tahun 1941, 1953 dan 1963. NEA merupakan sebuah organisasi yang profesinal dalam bidang pendidikan (Amerika). Di Indonesia prinsip kode etik guru sesuai dengan prinsip azasi "A Code Ethics for The Teaching Profession" yang dirumuskan NEA, tertuang dalam kongres PGRI yaitu pendidikan merupakan bentuk pengabdian kepada Tuhan Yang Maha Esa, bangsa dan tanah air dan kemanusiaan. Guru berjiwa Pancasila dan Undang-undang dasar 1945 dijadikan pedoman untuk mewujudkan cita-cita proklamasi kemerdekaan.

Kode etik profesi merupakan susunan etika yang dibentuk dari sebuah kesepakatan suatu kelompok masyarakat. Didalam kode etik terdapat norma social, dan norma hukum ( bila dalam kode etik memiliki sanksi berat). Kode itu juga merupakan tata cara, pedoman etis dan pola aturandalam pekerjaan dan kegiatan. Tujuannya untuk memberikan pelayanan dan jasa yang baik kepada para pemakai. Adanya kode etik dapat melindungi dari perbuatan yang tidak professional. Adanya sumpah pada kode etik guru dapat dijadikan sebagai pedoman, rem dan rambu-rambu agar setiap tindakan guru dapat dijaga khususnya saat kegiatan belajar mengajar berlangsung.

Mulyasa (2011) menyatakan bahwa sikap dan perilaku atau kode etik yang perlu dimiliki kepala sekolah adalah sebagai berikut. 1) Memiliki tanggung jawab terhadap jabatan yang dipercayakan kepadanya. 2) Memiliki kepedulian dan komitmen yang tinggi untuk mencapai sesuatu yang bermakna selama menduduki jabatannya. 3) Menegakkan disiplin waktu dengan penuh kesadaran bahwa disiplin merupakan kunci keberhasilan. 4) Melaksanakan setiap tugas dan kegiatan dengan penuh tanggung jawab, dan selalu jelas makna (value) dari setiap kegiatan dalam kaitannya dengan peningkatan mutu lulusan. 5) Proaktif (berinisiatif melakukan sesuatu yang diyakni baik) untuk peningkatan mutu pendidikan di sekolah, tidak hanya reaktif (hanya melaksanakan kegiatan jika ada petunjuk). 6) Memiliki kemauan dan keberanian untuk menuntaskan setiap masalah yang dihadapi oleh sekolahnya. 7) Menjadi leader yang komunikatif dan motivator bagi sifatnya untuk lebih berprestasi, serta tidak bersikap bossy (pejabat yang hanya mau dihormati dan dipatuhi). 8) Memiliki kepekaan dan merasa ikut bersalah terhadap sesuatu yang kurang pas, serta berusaha untuk mengoreksinya.
9) Berani mengoreksi setiap kesalahan secara tegas dan bertindak bijaksana, serta tidak permisif (mudah mengerti, maklum dan memaafkan kesalahan)

\section{Kompetensi kepala sekolah}

Kompetensi menurut Gilmore dan Carson (1996) yaitu kemampuan individu dalam menggunakan keterampilan dan ilmu pengetahuan dalam mencapai kinerja yang efektif. Karakteristik individu secara kausal memiliki hubungan dengan kinerja tertinggi disebut dengan kompetensi., situasi atau referensi kriteria secara efektif (Spencer \& Spencer 1993).

Berdasarkan Peraturan Menteri Pendidikan Nasional Nomor 13 Tahun 2007 tentang Standar Kepala Sekolah/Madrasah, dijelaskan bahwa seorang kepala sekolah harus memiliki kompetensi sebagai berikut:

Kompetensi Kepribadian: a. Berakhlak mulia, mengembangkan budaya dan tradisi akhlak mulia, dan menjadi teladan akhlak mulia bagi komunitas di sekolah/madrasah; b. Memiliki integritas kepribadian sebagai pemimpin; c. Memiliki keinginan yang kuat dalam pengembangan diri sebagai kepala sekolah/ madrasah; d. Bersikap terbuka dalam melaksanakan tugas pokok dan fungsi; e. Mengendalikan diri dalam menghadapi masalah dalam pekerjaan sebagai kepala sekolah/ madrasah; f. Memiliki bakat dan minat jabatan sebagai pemimpin pendidikan.

Kompetensi Manajerial: a. Menyusun perencanaan sekolah/ madrasah untuk berbagai tingkatan perencanaan; b. Mengembangkan organisasi sekolah/madrasah sesuai dengan kebutuhan; c. Memimpin sekolah/ madrasah dalam rangka pendayagunaan sumber daya sekolah/ madrasah secara optimal; d. Mengelola perubahan dan pengembangan sekolah/madrasah menuju organisasi pembelajar yang efektif; e. Menciptakan budaya dan iklim sekolah/ madrasah yang kondusif dan inovatif bagi pembelajaran peserta didik; $f$. Mengelola guru dan staf dalam rangka pendayagunaan sumber daya manusia secara optimal; g. Mengelola sarana dan prasarana sekolah/ madrasah dalam rangka pendayagunaan secara optimal; $h$. Mengelola hubungan sekolah/madrasah dan masyarakat dalam rangka pencarian dukungan ide, sumber belajar, dan pembiayaan sekolah/ madrasah; i. Mengelola hubungan sekolah/madrasah dan masyarakat dalam rangka pencarian dukungan ide, sumber belajar, dan pembiayaan sekolah/ madrasah; j. Mengelola peserta didik dalam rangka penerimaan peserta didik baru, dan penempatan dan pengembangan kapasitas peserta didik; k. Mengelola pengembangan kurikulum dan kegiatan pembelajaran sesuai dengan arah dan tujuan pendidikan nasional; 1. Mengelola keuangan sekolah/ madrasah sesuai dengan prinsip pengelolaan yang akuntabel, transparan, dan efisien; m. Mengelola ketatausahaan sekolah/madrasah dalam mendukung pencapaian tujuan sekolah/ madrasah; n. Mengelola unit layanan khusus sekolah/ madrasah dalam mendukung kegiatan 
pembelajaran dan kegiatan peserta didik di sekolah/ madrasah; o. Mengelola sistem informasi sekolah/ madrasah dalam mendukung penyusunan program dan pengambilan keputusan; p. Memanfaatkan kemajuan teknologi informasi bagi peningkatan pembelajaran dan manajemen sekolah/madrasah; q. Melakukan monitoring, evaluasi, dan pelaporan pelaksanaan program kegiatan sekolah/ madrasah dengan prosedur yang tepat, serta merencanakan tindak lanjutnya.

Kompetensi Kewirausahaan: a. Menciptakan inovasi yang berguna bagi pengembangan sekolah/ madrasah; b. Bekerja keras untuk mencapai keberhasilan sekolah/ madrasah sebagai organisasi pembelajar yang efektif; c. Memiliki motivasi yang kuat untuk sukses dalam melaksanakan tugas pokok dan fungsinya sebagai pemimpin sekolah/ madrasah; d. Pantang menyerah dan selalu mencari solusi terbaik dalam menghadapi kendala yang dihadapi sekolah/madrasah; e. Memiliki naluri kewirausahaan dalam mengelola kegiatan produksi/ jasa sekolah/ madrasah sebagai sumber belajar peserta didik.

Kompetensi Supervisi: a. Merencanakan program supervisi akademik dalam rangka peningkatan profesionalisme guru; b. Melaksanakan supervisi akademik terhadap guru dengan menggunakan pendekatan dan teknik supervisi yang tepat; c. Menindaklanjuti hasil supervisi akademik terhadap guru dalam rangka peningkatan profesionalisme guru.

Kompetensi Sosial: a. Bekerja sama dengan pihak lain untuk kepentingan sekolah/madrasah; b. Berpartisipasi dalam kegiatan sosial kemasyarakatan; c. Memiliki kepekaan sosial terhadap orang atau kelompok lain.

Kepala sekolah dituntut agar mampu dan memperlihatkan kinerja dalam aspek manajerial antara lain: 1) Menyusun rencana yang berkaitan dengan perencanaan tingkatan sekolah yang disesuaikan dengan kebutuhan; 3) Memimpin dalam konteks mendayagunakan sumber daya secara optimal yang berada dalam sekolah; 4) Pergeseran atau perubahan menuju sekolah yang efektif; 5) Menciptakan suasana dan budaya sekolah yang nyaman, man inovatif dalam kegiatan belajar mengajar; 6) Mengatur karyawan serta guru dalam mendayagunakan sumber daya manusia yang berada dalam sekolah secara menyeluruh; 7) Mengatur prasarana dan sarana dalam mendayagunakan yang ada di sekolah secara menyeluruh; 8) Mengatur atau menjalin hubungan antara masyarakat dan sekolah dalam konteks mencari pembiayaan dan sumber belajar yang berupa dukungan; 9) Melaksanakan kegiatan penerimaan atau orientasi peserta didik baru serta menempatkan dan mengembangkan kapasitas siswa; 10) Kegiatan pembelajaran sesuai dengan Kurikulum dan tujuan pendidikan yang telah ditentukan; 11) Mengatur anggaran yang disesuaikan dengan pengelolaan yang transparan dan dapat dipertanggungjawabkan; 12) Mengatur administrasi agar dapat memberikan dukungan dalam proses pencapaian tujuan yang direncanakan sekolah; 13) Memberikan dukungan pada kegiatan pembelajaran serta kegiatan di luar pembelajaran di sekolah; 14) Informasi agar dapat memberikan dukungan program dalam mengambil keputusan; 15) Teknologi informasi yang ada di sekolah dimanfaatkan agar dapat meningkatkan manajemen yang ada di sekolah; 16 ) Menerapkan dan melakukan evaluasi pelaksanaan program dan monitoring kegiatan yang ada di sekolah sesuai dengan prosedur, hal ini dilakukan karena untuk mengetahui sudah tercapaikah tujuan yang ditetapkan diawal atau belum tercapai, dengan adanya evaluasi dapat dijadikan sebagai bahan pertimbangan dalam pengambilan keputusan kedepanya dalam sekolah yang dipimpinnya.

Purba (2009) menjelaskan bahwa kompetensi kepala sekolah dapat terlihat dalam hal-hal sebagai berikut: 1). Memperlihatkan antara kemauan dan kecakapan dalam mengerjakan suatu pekerjaan; 2). Mempunyai kemampuan, kecakapan, pengetahuan, otoritas dan kemahiran dalam mengerjakan menunjukkan sifat orang-orang yang berkompeten; 3 ). Memperlihatkan kinerja secara rasional untuk mencapai tujuan-tujuan serta dapat memberikan kepuasan berdasarkan kondisi.

Juliantoro (2017) mengatakan bahwa sebagai top leader kepala sekolah memiliki kekuasaan, wewenang, dan kompetensi agar dapat mengembangkan serta mengatur karyawan secara profesional. Maka dari itu kepala sekolah hendaknya memiliki kompetensi sekolah sebagai manajer, sebagai pemimpin, sebagai pendidik, sebagai administrator, sebagai pencipta iklim kerja, dan sebagai penyelia.

\section{Strategi menjadi kepala sekolah profesional}

Beberapa hal yang dapat dilakukan untuk menjadi kepala sekolah profesional menurut Zulkifli (2014) ialah harus mengerti atau memahami secara komprehensif tentang kemampuan dan kinerja manajerialnya dalam konteks memimpin sebuah sekolah agar sekolah tersebut dapat bernuansa budaya yang sesuai dengan perkembangan masyarakat. Lebih lanjut Zulkifli mengemukakan bahwa kepala sekolah harus: a) Mempunyai pengetahuan serta wawasan yang jauh ke depan serta mengetahui tindakan apa yang harus dilakukan dan memahami tentang cara yang akan ditempuh; b) Mempunyai kemampuan dalam menyerasikan dan mengkoordinasikan sumber daya guna untuk mencapai dan memenuhi tujuan serta kebutuhan sekolah; c) Mempunyai keahlian dalam mengambil keputusan dengan akurat, cepat, tepat dan cekat; d) Mempunyai keahlian dalam memobilisasi sumber daya agar dapat mencapai dan menggugah bawahannya dalam melakukan atau dalam mencapai tujuan sekolah; e) Mempunyai toleransi terhadap perbedaan pada setiap orang.

Sudrajat (2008) seorang praktisi pendidikan Indonesia, menyampaikan 13 faktor kritis terkait dengan 
keberhasilan kepala sekolah dalam mengembangkan prestasi belajar siswa yang diidentifikasi oleh Southern Regional Education Board (SREB) berikut: 1). Menciptakan misi yang terfokus pada upaya peningkatan prestasi belajar siswa; 2). Ekspektasi yang tinggi bagi semua siswa dalam mempelajari bahan pelajaran; 3). Menghargai dan mendorong implementasi praktik pembelajaran yang baik; 4). Memahami bagaimana memimpin organisasi sekolah; 5). Memanfaatkan data untuk memprakarsai upaya peningkatan prestasi belajar siswa dan praktik pendidikan; 6). Menjaga agar setiap orang dapat fokus pada prestasi belajar siswa; 7). Menjadikan para orang tua sebagai mitra dan membangun kolaborasi untuk kepentingan pendidikan siswa; 8). Memahami proses perubahan dan mengelolanya; 9). Memahami bagaimana orang dewasa belajar; 10). Memanfaatkan dan mengelola waktu dengan cara-cara yang inovatif; 11). Memperoleh dan memanfaatkan berbagai sumber daya secara bijak; 12). Mencari dan memperoleh dukungan dari berbagai pihak; 13). Belajar secara terus menerus dan bekerja sama dengan rekan sejawat.

Sementara itu Solihin (2014) menjelaskan bahwa ada 7 hal yang dapat dilakukan untuk menjadi kepala sekolah inspiratif, yaitu: 1). Berakhlak mulia; 2). Cerdas; 3). Memiliki pandangan kedepan; 4). Memilki jiwa kreatif; 5). Tegas dan disiplin; 6). Humanis; 7). Memiliki integritas.

Berdasarkan penjelasan berbagai ahli tersebut, dapat penulis sampaikan bahwa strategi menjadi kepala sekolah profesional adalah: 1). Taat aturan. Yakni berbuat dan berkarya selalu berpedoman kepada aturan yang telah ditetapkan oleh negara, pemerintah daerah, dan aturan sekolah sendiri. 2). Meluangkan waktu. Yakni menjadi pribadi yang dapat menyediakan banyak waktu untuk sekolahnya, berinteraksi, berkolaborasi, dan bekerjasama dengan para guru, siswa dan warga sekolah lainnya untuk melakukan hal-hal positif demi kemajuan sekolahnya; 3). Peduli dan cepat tanggap. Yakni dapat membantu kerja guru dalam menafsirkankan gagasan besar dari pernyataan visi dan misi dalam praktik pelaksanaan kegiatan belajar-mengajar seharihari. Guru dapat melakukan hal-hal kreatif namun bukan karna ia manusia kreatif, namun karna ada kepala sekolah yang bersedia pasang badan jika terjadi masalah atau ia salah. Kepala sekolah juga peduli dan cepat terhadap para siswa, segera permasalahan yang dihadapi para siswa cepat direspon secara positif. Begitu juga terhadap warga sekolah lainnya, kepala sekolah menunjukkan kepedulian dan cepat tanggap akan berbagai permasalahan yang mereka hadapi; 4). Pemanfaatan IT. Yakni mengupayakan kehadiran internet yang mudah dan murah di sekolahnya, fasilitas internet yang bisa dimanfaatkan untuk berbagai kepentingan sekolah, seperti bisa mengatur dan mengubah jadwal, kepegawaian, penganggaran, dan struktur lain yang ada secara konkret, nyata, produktif, dan strategis. Termasuk juga melaksanakan berbagai kegiatan dan pekerjaan berbasis digital, sehingga informasi-informasi terkait sekolah dapat disampaikan kepada masyarakat secara cepat; 5). Pendampingan Akademik. Yakni menciptakan jalur akademis dalam mendukung peserta didik untuk sukses berdasarkan minat, keterampilan, dan bakat unik mereka. Baik menghubungkan inisiatif dan kemitraan kejuruan dan profesional, magang, serta yang akan membantu mengembangkan sekolah menjadi sekolah yang inovatif dan kreatif serta berdaya saing; 6). Inovatif. Menanam dan menumbuhkan inovasi dengan sukses serta mengantisipasi masalah yang mungkin muncul secara tiba-tiba dalam proses transformasi perubahan menuju kearah yang lebih baik.

\section{SIMPULAN}

Berdasarkan pemaparan tentang bagaimana strategi menjadi kepala sekolah profesional dapat disampaikan kesimpulan bahwa seorang kepala sekolah hendaknya memenuhi hal-hal sebagai berikut: 1). Taat aturan. 2). Meluangkan waktu. 3). Peduli dan cepat tanggap. 4). Pemanfaatan IT. 5). Pendampingan Akademik. 6). Inovatif.

\section{Saran}

Disarankan kepada para kepala sekolah agar bekerja dengan penuh kesungguhan hati, dan tampillah menjadi seorang kepala sekolah profesional, sehingga pencapaian tujuan pendidikan semakin mudah didapat.

\section{DAFTAR PUSTAKA}

Asmani, Jamal Ma'mur. (2012). Tips Menjadi Kepala Sekolah Profesional. Jogjakarta: DIV A Press.

Darmadi. (2018). Manajemen Sumber Daya Manusia Kekepala Sekolahan. Yogyakarta: Budi Utama.

Depdiknas. (2005). Kamus Besar Bahasa Indonesia. Cetakan Pertama Edisi Ketiga. Jakarta: Balai Pustaka.

Fullan, Michael, 2001. Leading in A Culture of Change, Jossey-Bass, San Francisco.

Gilmore, Audrey dan David Carson. (1996). Management Competence for Service Marketing. The Journal of Service Marketing, Vol 10, No. 3, pp, 39-57.

Harso, Muhdi. (2012). Pengaruh Kepemimpinan Kepala Sekolah dan Kinerja Guru Terhadap Keefektifan Sekolah di SMK kabupaten Pemalang. Educational Management. 1 (1) (2012): 10-17. http://journal.unnes.ac.id/sju/index.php/eduman.

Jelantik, A. K. (2015). Menjadi kepala sekolah yang profesional: Panduan menuju PKKS. Yogyakarta: Deepublish Publisher.

Juliantoro, M. (2017). Peran Kepala Sekolah dalam Meningkatkan Mutu Pendidikan. Jurnal AlHikmah, 5(2), 24-38. 
Mada Sutapa. (2006). Membangun Komunikasi Efektif di Sekolah". Jurnal Manajemen Pendidikan. Nomor 2. Tahun II. Oktober 2006: 69-76.

Maghfiroh, A. (2010). Peran Kepala Sekolah Sebagai Supervisor dalam Peningkatan Mutu Guru PAI di SMP Nasima Semarang. Disertasi. IAIN Walisongo.

Mahardhani, Ardhana Januar. (2015). Kepemimpinan Ideal Kepala Sekolah. Jurnal Dimensi Pendidikan dan Pembelajaran. Vol. 3 No. 2 Juli 2015: 1-4.

Mulyasa, E. (2011). Menjadi Kepala Sekolah Profesional. Bandung: Remaja Rosdakarya.

Muspawi, Mohamad, et.all. (2020). Upaya Kepala Sekolah Untuk Peningkatan Kompetensi Profesional Guru. Jurnal Ilmiah Universitas Batanghari Jambi, 20 (1), Februari 2020, pp.95103. DOI 10.33087/jiubj.v20i1.864. ISSN 14118939 (Online) | ISSN 2549-4236 (Print).

Nurmadiah. (2017). Profesionalisme Kepemimpinan Kepala Sekolah (kajian konsep dan teoritis). Jurnal keislaman \& peradaban volume 5 (1).

Peraturan Menteri Pendidikan Nasional Nomor 13 Tahun 2007 tentang Standar Kepala Sekolah/ Madrasah.

Peraturan Menteri Pendidikan Nasional Nomor 28 tahun 2010 Tentang Penugasan Guru Sebagai Kepala Sekolah/ Madrasah.

Peraturan Menteri Pendidikan dan Kebudayaan Nomor 6 tahun 2018 Tentang Penugasan Guru Sebagai Kepala Sekolah.

Peraturan Pemerintah Nomor 28 tahun 1990 tentang Pendidikan Dasar.

Purba, Sukarman. (2009). Peningkatan Kompetensi melalui Pementoran dalam Mewujudkan Profesionalisme Kepala Sekolah. Jurnal Unimed. volume 2 (2).

Septiana, et.all (2013). Pengaruh Kepemimpinan Kepala Sekolah dan Motivasi Kerja Terhadap Kinerja Guru SMP Negeri Wonosari. Jurnal Pendidikan Ekonomi UNS, Vol 2 No 1 tahun 2013: 107-118

Spencer, Lyle M and Signe M Spencer. (1993). Competence Work: Mode for Superior Performance. New York, USA: John Willey \& Sons, Inc.

Soewadji, Lazaruth. (1992). Kepala Sekolah dan Tanggung Jawabnya. Yogyakarta: Kanisius.

Solihin, Namin AB Ibnu. (2014). 7 Tips menjadi Kepala Sekolah Inspiratif:

https://motivatorkreatif.wordpress.com/2014/06/1 1/7-tips-menjadi-kepala-sekolah-inspiratif/. diakses 25-5-2020.

Sudrajat, Akhmad. (2008). 13 Faktor untuk Menjadi Kepala Sekolah yang Efektif. https://akhmadsudrajat.wordpress.com/2008/03/2 0/menjadi-kepala-sekolah-yang-efektif/. Diakses: 25-5-2020.
Syakir, Muhammad Junaidi \& Pardjono (2015). Pengaruh Kepemimpinan Kepala Sekolah, Motivasi Kerja, dan Budaya Organisasi Terhadap Kompetensi Guru SMA. Jurnal Akuntabilitas Manajemen Pendidikan. Volume 3, No 2, September 2015: 226-240.

Undang-Undang Republik Indonesia Nomor 14 Tahun 2005 Tentang Guru dan Dosen.

Wahjosumidjo. (2005). Kepemimpinan Kepala Sekolah. Jakarta. Raja Grafindo Persada.

Yahya, Murip. (2013). Profesi Tenaga Kependidikan. Pustaka Setia, Bandung.

Yuliani, Tri dan Kristiawan, Muhammad. (2016). Peran Kepemimpinan Kepala Sekolah Dalam Membina Kompetensi Sosial (Pelayanan Prima) Tenaga Administrasi Sekolah. Jurnal Manajemen, Kepemimpinan, dan Supervisi Pendidikan. Volume 1, No. 2, Juli-Desember 2016: 122-132.

Zacky. A (2016). Kode Etik Guru Dalam Meningkatkan Profesionalisme Pendidik; Reaktualisasi Dan Pengembangan Kode Etik Guru Di Madrasah Aliyah Darul Amin Pamekasan. Jurnal Pendidikan Agama Islam (Journal of Islamic Education Studies), 4(2), 271-292.

Zulkifli, Z. (2014). Strategi Kepala Sekolah Dalam Meningkatkan Kompetensi Profesional Guru Pada SMA Negeri 1 Peukan Bada Kabupaten Aceh Besar. Jurnal Ilmiah Didaktika: Media Ilmiah Pendidikan dan Pengajaran, 14 (2). 